\title{
The culture of benthic marine algae in the laboratory and the field
}

\author{
R. M. SMIth and W. E. Jones \\ University College of North Wales, Marine Science Laboratory; \\ Menai Bridge, Anglesey, U.K.
}

KURZFASSUNG: Die Kultur mariner Algen im Laboratorium und am natürlichen Standort. Der Aspekt der sublitoralen Algenvegetation vor der Küste von Ravenspoint (Westküste von Anglesey) wird entscheidend von der mechanischen Wellenwirkung, der Trübung des Wassers und der Sedimentierung geprägt. Auf den durch die Winterstürme stark verlagerten und abgescheuerten Steinen in $4 \mathrm{~m}$ Tiefe dicht unter der Küste kann sich erst ab April-Mai eine üppige Vegetation annueller Arten entwickeln. In $9 \mathrm{~m}$ Tiefe überstehen nur derbere Formen wie Chondrus oder Furcellaria die winterliche Sedimentablagerung. Hier stellen sich in den Somermonaten außer den auch in $4 \mathrm{~m}$ vorkommenden Arten einjährige Rotalgen wie Naccaria, Halarachnion, Scinaia und Helminthora ein. Zur Klärung ihrer Okologie und Lebensgeschichte wurden Steine ins Laboratorium verbracht und der sich entwickelnde Aufwuchs untersucht, außerdem Kulturen dieser Arten auf Objektträgern im Laboratorium und am natürlichen Standort verglichen. Besonderes Interesse verdienen Vertreter der Nemalionales (Rhodophyceae), in deren Lebenszyklus bisher nur die karposporentragende Phase bekannt ist. Zwei Monate alte Kulturen von Naccaria wurden im November aus dem Laboratorium an ihren natïrlichen Standort gebracht. Nach gleichartiger Entwicklung bis zum Mai des folgenden Jahres bildeten sie Strukturen, die vielleicht der tetrasporentragenden Phase entsprechen. Solche Stadien wurden während der dreijährigen Kultur im Laboratorium nicht beobachtet. Daher ist eine kritische Beurteilung der an Laboratoriumskulturen erhaltenen Ergebnisse angezeigt, besonders bei der Untersuchung des Lebenszyklus von Algen. Die Zellenanordnung junger Corallinaceen-Krusten zeigte charakteristische Unterschiede, die vielleicht als taxonomische Kriterien verwertbar sind.

\section{INTRODUCTION}

This work forms part of an investigation of a number of problems concerned with the ecology of the sub-littoral benthic marine algae. On the west coast of Anglesey (U. K.) at Treaddur Bay, there is a seasonal development of an algal flora on a substratum of loose stones in the sub-littoral region. Collections have been made from 3 distinct regions representing 3 different habitats at depths of 4,9 and $30 \mathrm{~m}$ below low water mark.

At $4 \mathrm{~m}$ the stone bed was found to lie $10 \mathrm{~m}$ away from the steep rocky shore. Movement of the stones accurred in winter partly because of the action of heavy swells passing over the bed and because of the turbulence resulting from the reflection 
of the swells from the rock face. The movement of the stones was sufficient to abrade from their surfaces all the visible algae which had developed there during the summer months. From April to May onwards, the duration and intensity of the storms was insufficient to cause movement of the stone bed. During this stable period, the reduced water movement resulted in a decrease in the sediment load, thus allowing greater penetration of light and the water temperature reached about $10^{\circ} \mathrm{C}$ at the same time. Soon after this, a large number of species developed on the stones resulting in a luxuriant plant cover.

At a depth of $9 \mathrm{~m}$ the stone bed was not subjected to much movement and the mutual abrasion of the stone surfaces was slight. However, the stones became covered during the winter months with a layer of sand and shell gravel of variable depth. This was sufficient to destroy all but the larger cartilagenous species [Chondrus crispus STACKH., Furcellaria fastigiata LAMOUR and Rhodomela confervoides (Huds.) Silva] of a population which had developed during the summer months. This population included most of the species recorded at $4 \mathrm{~m}$ and, in addition, species of annual red algae, in particular Naccaria wiggii (Turn.) Endu., Halarachnion ligulatum (Woodw.) KüTz, Scinaia furcellata (TurN.) Brv., Helminthora divaricata (C. AG.) J. AG. In order to investigate the origins and fate of the summer flora of the stone beds, 3 lines of study were pursued. Firstly, the culture of the main components of the flora was attempted; secondly, stones from the sub-littoral stations were collected and transferred to laboratory culture conditions and, thirdly, the development of spores of some species was observed both in the laboratory and in the field.

The stones from $30 \mathrm{~m}$ depth were collected on a dive $5.6 \mathrm{~km}$ North-West of the station sites of the 4 and $9 \mathrm{~m}$ collections. The object of the dive was to establish the limit of the penetration of algae below the tide level. At this station the limit of growth was found to be $25 \mathrm{~m}$, at the fringe of a region of heavy sedimentation on the rock surfaces. Stones from $30 \mathrm{~m}$ appeared to be without algae on the surface even when examined with a stereo-microscope. The examination of rock scrapings from this depth also failed to reveal algal growth.

\section{MATERIAL AND METHODS}

Material for work on spore development was obtained from the algae collected at local sites. The fertile material was placed over glass or roughened perspex microscope slides in dishes of sea water in the laboratory. After $24 \mathrm{~h}$, during which time mature spores were shed, the plant material was removed and the slides were left for a further $24 \mathrm{~h}$ to facilitate spore attachment. The slides were then transferred, with the attached spores, to running sea water under illumination regimes which are summarised in Table 1. The illumination was provided by Atlas Daylight fluorescent tubes, and was measured by an EEL photometer of the selenium barrier cell type.

Stones collected from the sub-littoral stone beds were placed in deep dishes, fully submerging each rock. The laboratory regimes are summarised in Table 2. Material incubated at temperatures higher than laboratory temperature was cultured in dishes 
placed in a water bath. The sea water used in these cultures was untreated sea water, filtered through glass wool to remove the diatoms, and was changed weekly. All materials on slides and stones maintained at laboratory temperature were placed in the recirculating sea water system described by Jones \& DENT (1970). The flow rate

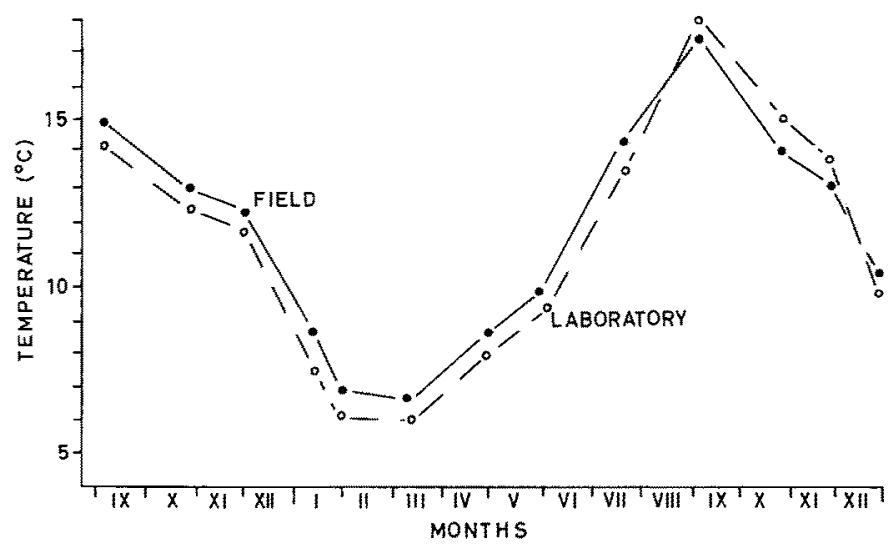

Fig. 1: Variation of sea water temperature during experiments

of the water through the dishes was $0.0141 / \mathrm{sec}$. The laboratory temperature maintained by this system is shown in Figure 1 together with temperatures measured in the field during the experiment. Illumination received by the plants in the field was calculated according to the method outlined by SMrTH \& JonEs (1970). Field light readings were measured at the surface, at 4 and $9 \mathrm{~m}$. The readings were integrated over the day to allow for diurnal variation in radiation. From the integrated value laboratory 'daylength' was calculated to irradiate the sporelings with the same total radiation being received by plants in the field. Adjustments for seasonal variation were made from time to time.

\section{RESULTS AND DISCUSSION}

\section{General effects of the regimes on the growth of the algae}

In general the rate of growth of plants in the laboratory was slower than that of the same species in the field. The reaction of sporelings to the irradiation regimes often complemented the observed distribution of the plant in the field.

Thus it will be seen in Table 1 that Cbondrus crispus STAckH., found in the littoral region in the rock pools and also recorded throughout the sub-littoral to the substrate limit of $10 \mathrm{~m}$, shows a remarkably uniform growth index over the whole range of irradiation levels. Delesseria sanguinea (HUDs.) LAMOUR, a plant with the same range of distribution but limited in the littoral region to positions of total shade in pools, showed a markedly different reaction. In the sub-littoral, plants 
restricted to the shade of steep sided gullies were often influenced by the canopy shade of Laminaria byperborea (GUNN) FosLE. The growth of the sporelings of $D$. sanguinea was adversely affected by irradiation intensities of 1000 lux at the 4 celled stage. This corresponds to the highest irradiation level measured at the site

\section{Table 1}

Comparative development of spores and sporelings cultured under laboratory and field conditions. Irradiation levels in the laboratory were determined using a barrier-layer photocell. The 4 and $9 \mathrm{~m}$ depths of the field cultures represented irradiation levels of approximately 100 and 750 lux, respectively. Growth index of sporelings used: $0=$ dead; $1=$ spores alive but undivided; $2=$ little development beyond initial divisions; 3 = poor development spore-

ling; $4=$ normal development but smaller than $5 ; 5=$ good development of sporeling

\begin{tabular}{|lcccccccc|}
\hline & \multicolumn{3}{c}{ Irradiation levels (lux) } & \multicolumn{3}{c|}{ Depth of field cultures (m) } \\
\hline \multicolumn{1}{c}{ Species } & 180 & 200 & 360 & 500 & 1000 & 4 & 9 \\
\hline Laminaria hyperborea & 5 & 5 & - & - & - & 0 & 5 \\
Delesseria sanguinea & 5 & 5 & 3 & 3 & 0 & 0 & 0 \\
Hypoglossum woodwardii & 5 & 5 & 5 & 5 & 5 & 0 & 5 \\
Chondrus crispus & 5 & 5 & 5 & 5 & 5 & 5 & 5 \\
Callophyllis laciniata & 5 & 5 & 5 & 4 & 3 & 0 & 5 \\
Rbodomela confervoides & 5 & 5 & 5 & 5 & 5 & 5 & 5 \\
Polysiphonia elongata & 5 & 5 & 0 & 0 & 0 & 5 & 5 \\
Litbopbyllum sp. & 5 & 5 & 5 & 5 & 5 & 5 & 5 \\
Corallina sp. & 5 & 5 & 5 & 5 & 5 & 5 & 5 \\
Lithothamnion sp. & 5 & 5 & 5 & 5 & 5 & 5 & 5 \\
Rhodymenia palmata & 0 & 0 & 4 & 5 & 5 & 5 & 5 \\
\hline
\end{tabular}

of a fertile $D$. sanguinea. Thus, the distribution of this species may be a result of the reaction of the sporeling to the irradiation level. The species has a restricted period of spore release between January and March. Plants derived from tetraspores and carpospores showed similar reactions. There appears to be no difference in the distribution of the two reproductive phases in the field.

Species transferred to the frames in the field showed one of two contrasting reactions. Plants would either develop well (often to maturity) or disappear from the culture slide. The reason for the disappearance of some species was probably twofold: firstly, a plant developing poorly would survive only a very short time under natural conditions of water movement; secondly, the high density of grazing animals would constitute another hazard. The grazing of Gibbula cinerea, in particular, must account for the loss of a high proportion of both healthy and poorly developing plants. Trails left by the radulae of grazing animals were clearly visible on the slides. The efficiency of their grazing was high, even small coralline crusts were damaged. Densities of up to 50 animals $/ \mathrm{m}^{2}$ were measured.

The development of the coralline algae was particularly interesting. The plates of cells which developed from the spores had a similar growth index at all irradiation levels. Calcification of the cell wall occurred at the 4-cell stage. Five types of coralline plates could be distinguished by their cell pattern; three genera of these forms have been identified. The identity of Corallina officinalis L. was uncertain until the characteristic vertical filaments arose from the plates. Subsequent examination of calcified plates in the field enabled the investigators to distinguish Corallina in the 
field from other calcified crusts under natural conditions when upright filaments were absent. Plates of Litbopbyllum sp. became rapidly fertile in the laboratory under a wide range of irradiation levels. The typical cystocarps with a single ostiole developed on plates $80 \mu$ and larger in diameter. The cell arrangement of the plates was typical of specimens growing as epiphytes on Furcellaria in the field. The cell arrangement of the third type of plate quickly became obscured as the result of divisions of the cells in the horizontal plane. Larger specimens grown in the laboratory and the field showed the characteristic form of Lithothamnion sp. No differences attributable to speciation could be distinguished at this stage. The other two forms observed have not yet been identified.

\section{Culture of algae on stones from sub-littoral stations}

The results of cultivating algae on stones are summarised in Table 2. Complete absence of algal development from stones collected at $4 \mathrm{~m}$ depth confirmed the initial field observations that the movement to which the stones had been subjected destroyed all algae present, including sporelings and perennating bases. This fact indicates that the summer population develops entirely by recruitment of spores from plants already established on the surrounding rodks and the littoral region. The presence of sporelings of Fucus sp. (probably F. serratus L.), confirms the latter

Table 2

Culture of algal material present on the surface of stones collected in the sub-littoral in autumn. The stones were placed in the culture medium intact. In all cases the numbers of species present increased during the period of culture, indicating that perennating structures such as spores or vegetative fragments were present on the stones at the time of collection

\begin{tabular}{|c|c|c|c|c|c|c|}
\hline \multirow{2}{*}{$\begin{array}{l}\text { Environmental } \\
\text { parameters }\end{array}$} & \multirow{2}{*}{$\begin{array}{l}\text { Photoperiod (h) } \\
\text { Irradiation (lux) } \\
\text { Temperature }\left({ }^{\circ} \mathrm{C}\right) \\
\text { Depth of origin } \\
\text { of material }(\mathrm{m})\end{array}$} & $\begin{array}{c}12 / 12 \\
180 \\
18^{0}\end{array}$ & $\begin{array}{c}12 / 12 \\
180 \\
\text { Laboratory }\end{array}$ & $\begin{array}{l}\text { Laboratory } \\
\text { Laboratory } \\
\text { Laboratory }\end{array}$ & \multicolumn{2}{|c|}{$\begin{array}{c}\text { Laboratory } \\
0.1 \\
\text { Laboratory }\end{array}$} \\
\hline & & 49 & 4925 & $4 \quad 925$ & 4 & 925 \\
\hline $\begin{array}{l}\text { Number of } \\
\text { species recorded }\end{array}$ & $\begin{array}{l}\text { October } \\
\text { February } \\
\text { March }\end{array}$ & $\begin{array}{lr}0 & 8 \\
0 & 11 \\
0 & 11\end{array}$ & $\begin{array}{rrl}0 & 7 & 0 \\
0 & 6 & 1^{*} \\
0 & 12 & 3\end{array}$ & $\begin{array}{rrr}0 & 7 & 0 \\
0 & 7 & 0 \\
0 & 15 & 1\end{array}$ & $\begin{array}{l}0 \\
0 \\
0\end{array}$ & $\begin{array}{ll}7 & 0 \\
7 & 0 \\
9 & 0\end{array}$ \\
\hline * Laminaria by & & & & & & \\
\hline
\end{tabular}

assumption. The stones collected at $9 \mathrm{~m}$ gave rise to specimens belonging to a number of species not visible when the stones were first collected. As the control surfaces remained clean, the origin of these plants was undoubtedly from overwintering spores and vegetative fragments, e. g. basal discs and flaments. From the time at which the plants appeared under the laboratory regimes used, it may be deduced that temperature is an important factor in determining the development of these species. Presumably, the increased irradiation in April and May is important in stimulating the development of the sporelings in the field. Plants developing under approximately 
0.1 Iux in the laboratory grew much more slowly than plants under the other 3 regimes.

The populations which developed in the laboratory on the stones from $9 \mathrm{~m}$ depth contained most of the components of the populations that developed in the field during the same period, with some exceptions. These exceptions included the following species of red algae - Naccaria wiggii (TURner) ENDL., Scinaia furcellata (TURNer) Brv., Helminthora divaricata (C. Ag.) J. Ag., Halarachnion ligulatum (Woodw.) Kütz. The significance of the absence of these species is that they are seasonal forms present between July and October; only the cystocarpic generation is represented. The alternate tetrasporic generation is known only for Halarachnion ligulatum (BoIloot 1965). The absence of these species on the stones in the laboratory prompted further investigation of their life histories.

The stones from $30 \mathrm{~m}$ depth were devoid of any algal growth when collected in September. They formed part of a rocky face continuous from the upper littoral to a depth of $35 \mathrm{~m}$. The limit of algal growth was found to be $25 \mathrm{~m}$ at this station. Plants of Delesseria sanguinea, Pbyllophora crispa (Huds.) Dixon and Plocamium cartilaginum (L.) Drxon persisted to $20 \mathrm{~m}$. Phyllopbora crispa penetrated a further $5 \mathrm{~m}$. During maintenance of the stones in the laboratory, the appearance of Laminaria hyperborea during January and Chaetomorpha melagonium (WEB \& MoнR) Kürz and Phyllophora crispa in March suggests that the limit of algal growth at $25 \mathrm{~m}$ may be a result of low irradiation. There is no doubt that these conditions exist; the sediment load of the water is high and the settled sediment, which covers all the rock surfaces within $10 \mathrm{~m}$ of the stone bed, has a blanketing effect. The sea bed seawards from this station consisted of fine yellow mud.

\section{Culture of seasonal species}

The initial development of seasonal species showed stages which have been described by other workers, in particular CHEMIN (1927). Naccaria wiggii was cultured in the laboratory under regimes summarised in Table 3.

So far, the evidence of BoIllot (1968) suggests that there is no alternate tetrasporic phase in Naccaria wiggii. Carpospores of $N$. wiggii give rise, in the

Table 3

Culture of filaments derived from carpospores of Naccaria wiggii. Laboratory regimes were designed to determine the irradiation/daylength/temperature requirements of tetraspore formation. Tetrasporic $N$. wiggii have not been recorded from the field under natural conditions. M: Monosporangia; T: Tetrasporangia; Lab.: laboratory

\begin{tabular}{|c|c|c|c|c|c|c|}
\hline $\begin{array}{l}\text { Environmental } \\
\text { parameters }\end{array}$ & $\left\{\begin{array}{l}\text { Photoperiod }(\mathrm{h}) \\
\text { Irradiation }(\mathrm{lux}) \\
\text { Temperature }\left({ }^{\circ} \mathrm{C}\right)\end{array}\right.$ & $\begin{array}{c}12 / 12 \\
180 \\
18^{0}\end{array}$ & $\begin{array}{l}12 / 12 \\
180 \\
\text { Lab. }\end{array}$ & $\begin{array}{l}\text { Lab. } \\
\text { Lab. } \\
\text { Lab. }\end{array}$ & $\begin{array}{l}\text { Lab. } \\
.1 \\
\text { Lab. }\end{array}$ & $\begin{array}{l}\text { Field Lab. } \\
\text { Field } \\
\text { Field }\end{array}$ \\
\hline $\begin{array}{l}\text { Type of spore } \\
\text { present }\end{array}$ & $\left\{\begin{array}{l}\text { January } \\
\text { June }\end{array}\right.$ & $\underline{M}$ & M & $\underline{M}$ & $\mathrm{M}$ & $\begin{array}{l}\mathrm{M} \\
\mathrm{T}\end{array}$ \\
\hline
\end{tabular}


laboratory, to filaments from which cystocarpic plants are directly derived. During our work, the filaments grown in laboratory culture failed to develop any structures that could be recognised as the possible tetrasporic generation. The cultures were maintained for 3 years. Slides bearing filaments derived from the carpospores were transferred to the field. These filaments showed a pattern of development similar to the laboratory cultures until the beginning of summer. At this time crowded vertical filaments arose from the creeping filaments, and structures resembling the tetrasporangia of Rhodochorton sp. developed in terminal and lateral positions. The contents of these sporangia were released and behaved as spores, giving rise to filaments morphologically similar to the filaments derived from the carpospores. These are now in field culture. The difference between the results of laboratory and field cultures illustrates the care with which life history studies should be interpreted when algae are maintained in laboratory culture only.

\section{CONCLUSION}

The 3 topics discussed here show the value of close comparisons between culture of marine algae in the laboratory and the field. The clarification of the identification of coralline crusts in the field is most important taxonomically and should also assist ecological work which is so far lacking on these forms. Further work in the field should aid the identification of the plate types which have, as yet, been observed in the laboratory only.

\section{SUMMARY}

1. Growth and development of algae from spores has been observed in the laboratory (Menai Bridge) and under field conditions at Ravenspoint (West coast of Anglesey). Attempts were made to culture all main components of the sub-littoral flora. Spore material was obtained from spores allowed to settle onto plastic slides in the laboratory sea water system and from spores settled on slides stationed in the field.

2. Attention was given to the summer annual species and, in particular, to those members of the Nemalionales (Rhodophyceae) which have incompletely known life histories. In these plants, the tetrasporic phase during which reduction division normally takes place, has so far been undetected in the field. The plants are represented by the cystocarpic phase of the life cycle only.

3. The fate of the carpospores of these species were of particular interest. The spores of the annual species were cultivated under a number of regimes of irradiation and temperature. Sporelings from laboratory culture were transferred to the field in November, 2 months after settlement. Both in laboratory and field, the form of development of the cultures were similar until May of the following year. Then the field cultures developed structures which may represent the tetrasporangia of the alternate phase. These structures failed to develop in the laboratory cultures after 3 years. 
4. The results of these experiments illustrate that care must be taken in interpreting results of laboratory cultures of algae, in particular in regard to their life histories.

\section{LITERATURE CITED}

Bonlot, A., 1968. Sur l'existence d'une tetrasporophyte dans le cycle de Scinaia furcellata (Turn.) BIV. C. r. Séanc. Acad. Sci., Paris 266, 1813-1832 P. 1265.

Chemin, 1927. Sur le développement des spores chez quelques Nemalionalees. Bull. Soc. bot. Fr. 74, 163-167.

Jones, W. E. \& DENT, E. S., 1970. Culture of marine algae using a recirculating sea water system. Helgoländer wiss. Meeresunters. 20, 70-78.

Smith, R. M. \& Jones, W. E., 1970. Measurement of submarine illumination. In: Proceedings of the 4th European Symposium on marine biology, Bangor (Wales), 1969. Univ. Press, Cambridge (in press).

First author's adress: R. M. SMITH University College of North Wales

Marine Science Laboratory

Menai Bridge, Anglesey, U.K. 